\title{
$\left[\begin{array}{l}\text { PEN } \\ \text { ACCESS }\end{array}\right]$
}

\section{Diel distribution and feeding habits of Neomysis mirabilis under seasonal sea ice in a subarctic lagoon of northern Japan}

\author{
Kazutaka Takahashi ${ }^{1, *}$, Norio Nagao $^{2}$, Satoru Taguchi ${ }^{3}$ \\ ${ }^{1}$ Department of Aquatic Bioscience, Graduate School of Agricultural and Life Sciences, The University of Tokyo 1-1-1, Yayoi, \\ Bunkyo-ku, Tokyo 113-8657, Japan \\ ${ }^{2}$ Institute of Bioscience, Universiti Putra Malaysia, 43400 Serdang, Selangor Darul Ehsan, Malaysia \\ ${ }^{3}$ Faculty of Engineering, Soka University, 1-236 Tangi-cho, Hachioji, Tokyo 192-8577, Japan
}

\begin{abstract}
We investigated the diel distribution and feeding habits of the mysid Neomysis mirabilis under seasonal sea ice in a subarctic lagoon of northern Japan. Although large individuals (>11 mm total length) were present in the eelgrass beds regardless of the time of day, smaller individuals only migrated to the eelgrass beds at night, possibly from shallower waters. Investigation of their stomach contents revealed that $N$. mirabilis is primarily dependent on eelgrass epiphytes as a food source, in addition to small crustaceans. Calculations based on gut pigment analysis indicated that epiphytes were sufficient for large mysids to fulfill their metabolic requirements, whereas small mysids needed to ingest additional food items, such as small crustaceans, possibly because they were less able to graze the highly adhesive prostrate epiphytes. This study suggests that grazing on epiphytes could be a third option in the feeding habits of mysids (in addition to suspension-feeding and predation), and is beneficial in maintaining their high biomass, even during the winter.
\end{abstract}

KEY WORDS: Crustaceans $\cdot$ Mysidacea $\cdot$ Overwintering $\cdot$ Distribution $\cdot$ Sea ice $\cdot$ Eelgrass $\cdot$ Epiphytes

\section{INTRODUCTION}

Mysids belonging to the genus Neomysis (Mysidae, Crustacea) occur abundantly in lagoons and estuaries of the subarctic north-western Pacific coast (Pecheneva et al. 2002, Yamada et al. 2007, Yusa \& Goshima 2011). Neomysis is an omnivore, feeding on detritus, algae and animal prey (Baldo-Kost \& Knight 1975, Siegfried \& Kopache 1980, Fockedey \& Mees 1999). The success of Neomysis in coastal habitats is largely attributed to its ability to adapt to variable environments, typically represented by a tolerance to low salinity and a wide range of water temperatures (Simmons \& Knight 1975, Pezzack \& Corey 1982, Roast et al. 1999). Mysids in coastal lagoons at high latitudes, however, experience particularly harsh en-

\footnotetext{
*Corresponding author: akazutak@mail.ecc.u-tokyo.ac.jp
}

vironments during the winter, when, in addition to below-freezing temperatures, water surfaces are covered with seasonal sea ice, resulting in dramatically decreased primary productivity in the water column (Tada et al. 1993). Secondary production by planktonic copepods is also depressed (Fortier et al. 1995). Nevertheless, mysids are often the most dominant organisms in terms of biomass in the zooplankton community under seasonal sea ice (Fukuchi et al. 1979, Fortier \& Fortier 1997). These observations indicate that mysids are important components of the ecosystem; however, the detailed ecology of mysids under sea ice has not been fully elucidated, partly due to the difficulty of quantitative sampling (see Fukuchi et al. 1979). In this study, we investigated vertical distribution and feeding habits of Neomysis

() The authors 2015. Open Access under Creative Commons by Attribution Licence. Use, distribution and reproduction are unrestricted. Authors and original publication must be credited. 
mirabilis (Czerniavsky, 1882) below seasonal sea ice, in order to examine the mechanisms by which they maintain their high abundance during the productively poor winters in subarctic coastal lagoons.

\section{MATERIALS AND METHODS}

Sampling was conducted at Saroma-ko lagoon $\left(44^{\circ} 10^{\prime} \mathrm{N}, 143^{\circ} 45^{\prime} \mathrm{E}\right)$ in eastern Hokkaido, northern Japan (Fig. 1). Saroma-ko lagoon covers an area of about $152 \mathrm{~km}^{2}$, and is the southernmost locale where sea ice forms in the northern hemisphere (Taguchi \& Takahashi 1993). In normal years, 30 to $40 \mathrm{~cm}$ thick ice covers the lagoon from December to late March, resulting in low light conditions in the water column. During this period, the production of ice algae, which is well adapted to such environments, surpasses that of phytoplankton and benthic microalgae (McMinn et al. 2005). In addition, the study site contains one of the largest eelgrass Zostera marina beds in the world (Katsuki et al. 2009); the eelgrass and its associated epiphytes are an important food source for aquatic animals (e.g. Aya \& Kudo 2007, Yamada et al. 2010).

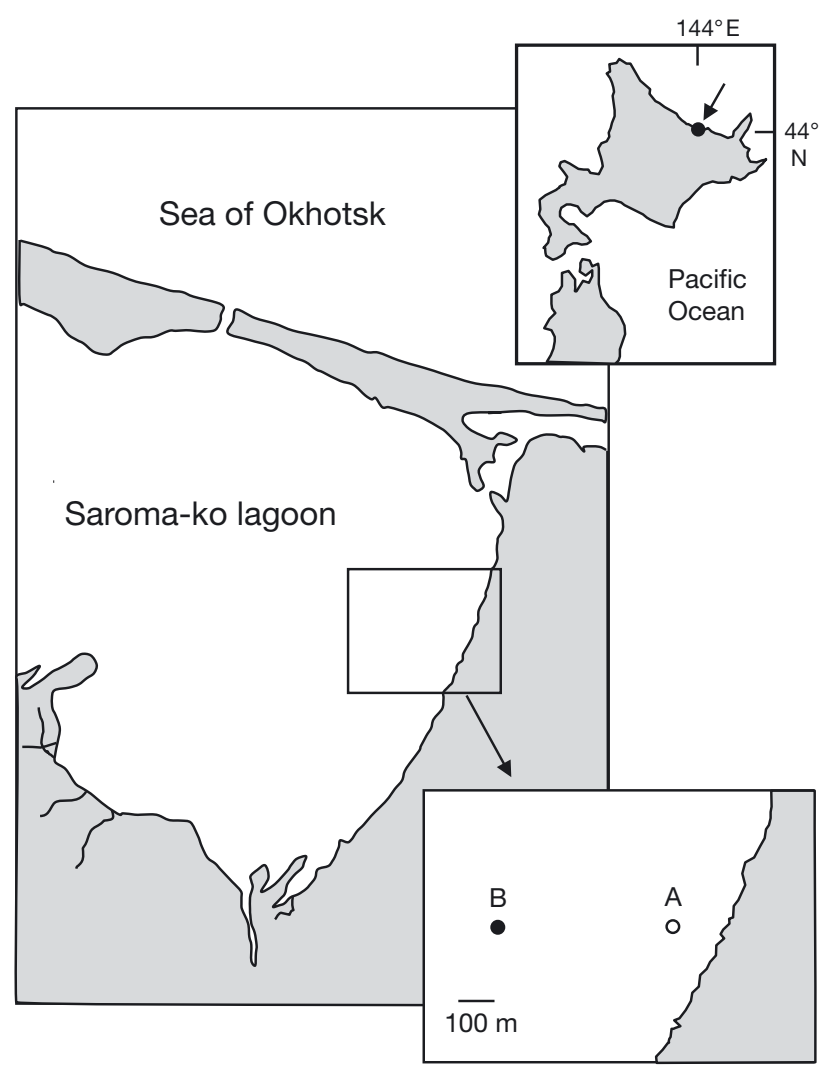

Fig. 1. Location of Saroma-ko lagoon (arrow) and sampling sites in Hokkaido, northern Japan. Stn A: near-shore eelgrass bed; Stn B: offshore muddy bottom
Vertical distribution patterns and feeding habits of Neomysis mirabilis were investigated at 2 sampling stations in Saroma-ko lagoon: Stn A, $100 \mathrm{~m}$ from shore at a depth of $2 \mathrm{~m}$ with a bottom covered with eelgrass beds; and Stn B, $600 \mathrm{~m}$ from shore at a depth of $5 \mathrm{~m}$, characterized by a muddy bottom lacking vegetation (Fig. 1). Both stations were covered by $35 \mathrm{~cm}$ thick sea ice. Mysids were sampled from 3 layers: near the bottom, immediately under the sea ice, and in between. A conical plankton net $(30 \mathrm{~cm}$ diameter, $330 \mu \mathrm{m}$ mesh) was used to sample the upper 2 layers in the water column, and a sledge net (10 $\mathrm{cm}$ high $\times 30 \mathrm{~cm}$ wide, with $330 \mu \mathrm{m}$ mesh) was used for near-bottom sampling. During all sampling events, the gear was attached to a rope, forming a loop between 2 holes that were $20 \mathrm{~m}$ apart in the ice, and towed horizontally with a constant towing speed (ca. $0.7 \mathrm{~m} \mathrm{~s}^{-1}$ ). Spherical buoys mounted on the frame of the plankton net allowed us to sample the layer immediately under the ice. To sample the middle layer, the plankton net was towed between stainless steel eye bolts attached to a square post that was vertically set in the ice holes. The positions of the eye bolts were adjusted to the middle point of the sampling site depths (1 and $2.5 \mathrm{~m}$ for Stns A and B, respectively), and the looped rope was tensioned between the eye bolts when towing the plankton net, which was fastened between the looped rope, in order to sample at a constant depth in the water column. Filtered water volume was estimated as the product of the distance between holes and the area of net opening or sledge mouth. Samples were taken every $3 \mathrm{~h}$ for $24 \mathrm{~h}$, from $07: 00 \mathrm{~h}$ on 27 February to 07:00 h on 28 February 1998, although sampling at Stn B was not conducted after 22:00 h due to thick fog which prevented us from reaching the sampling station. All collected samples were immediately frozen in dry ice and kept at $-80^{\circ} \mathrm{C}$ in the dark until analysis. In the laboratory, the frozen samples were thawed using chilled, filtered seawater, and the mysids were identified and counted using a dissecting microscope under dim light.

As an index of feeding activity, diel changes in gut pigment content were determined. Specimens were rinsed with filtered seawater and then dipped into $4 \mathrm{ml}$ of $\mathrm{N}, \mathrm{N}$-dimethylformamide to extract the gut pigments (Suzuki \& Ishimaru 1990). Between 5 and 40 extraction bottles were prepared for each sampling time, depending on the number of mysids in the samples. The extraction bottles were kept at $-20^{\circ} \mathrm{C}$ in darkness until analysis (>24 h). Pigment concentrations were measured using a Turner Model 111 fluorometer. Gut pigment content was expressed as 
chlorophyll a $(\mathrm{chl} a)+$ phaeopigments in a chl $a-$ equivalent weight per body dry weight (DW) to take into account variations in body size. Body DW was estimated after Shushkina et al. (1971) from body length, which was measured under the microscope.

Prey items of the mysids were observed using scanning electron microscopy (SEM; JSM-T100). The specimens were fixed with $4 \%$ glutaraldehyde immediately after thawing. Under a dissecting microscope, the foregut was carefully removed and divided using the dry fracturing method (Toda et al. 1989). The guts of 10 mysids from the day $(13: 00 \mathrm{~h})$ and 10 mysids from the night $(22: 00 \mathrm{~h})$ were examined. The mean $( \pm \mathrm{SD})$ total lengths (TL) of the specimens from which stomach contents were examined were $12.3 \pm 1.3$ and $11.7 \pm 1.3 \mathrm{~mm}$ for day and night, respectively.

In order to investigate potential food items in the environment, the taxonomic characteristics of microalgae (phytoplankton, ice algae, and epiphytes on the eelgrass) were examined at Stn A. Phytoplankton was collected from the ice-water interface (surface) and the near-bottom layer using a Niskin bottle. Ice algae were collected from an ice core that was taken in the vicinity of the sampling hole, using an ice core sampler. Leaves of $Z$. marina were obtained from the ice hole at Stn A, and the microalgal mats (epiphytes) on the leaves were collected by scraping the surface of each leaf with a knife and suspending it in filtered seawater. All samples were preserved in $4 \%$ Lugol's solution. Taxonomic identification and enumeration of algal species was conducted using light microscopy. Over 400 cells were counted in each sample to avoid the effect of sample size on the relative abundances of each species.

Based on the diel changes in mean gut pigment, the grazing rate on algal prey was estimated for different size classes using the gut fluorescence method (Mackas \& Bohrer 1976). The gut evacuation rate at the in situ temperature $\left(-1^{\circ} \mathrm{C}\right)$ was estimated as $0.1572 \mathrm{~h}^{-1}$ based on the temperaturedependent relationship in Mysis relicta, with a $Q_{10}$ function of 1.93 (Chipps 1998). Although M. relicta is a freshwater species, its size and the temperature of its habitat are similar to that of $N$. mirabilis. Carbon grazing rates were estimated using a $\mathrm{C}: \mathrm{chl}$ a ratio of 47.63 (De Jonge 1980). The daily metabolic requirement of $N$. mirabilis ( $\mu \mathrm{g} \mathrm{C}$ ind. ${ }^{-1}$ $\mathrm{d}^{-1}$ ) at $-1^{\circ} \mathrm{C}$ was estimated from its DW ( $\mu \mathrm{g}$ ind.$^{-1}$ ) using an empirical allometric relationship (Ikeda $1985)$ for the oxygen consumption rate, $\mathrm{RO}\left(\mu \mathrm{l} \mathrm{O}_{2}\right.$ ind. $^{-1} \mathrm{~h}^{-1}$ ). The estimated RO was converted to respiratory carbon equivalents, $\mathrm{RC}\left(\mu \mathrm{g} \mathrm{C}\right.$ ind.$\left.^{-1} \mathrm{~d}^{-1}\right)$ as $\mathrm{RC}=\mathrm{RO} \times \mathrm{RQ} \times 12 / 22.4 \times 24$, where $\mathrm{RQ}$ (respiratory quotient) is the molar ratio of carbon produced to oxygen utilized, 12 is the atomic weight of carbon, 22.4 is the molar volume of an ideal gas at standard temperature and pressure, and 24 is the number of hours per day. We used an RQ of 0.97 , assuming a protein-based metabolism (Gnaiger 1983). The assimilation efficiency was assumed to be $80 \%$, which is a general value for algal prey (Takahashi 2004).

\section{RESULTS}

Four species of mysids, including 3 species of Neomysis, were collected from under the sea ice (Table 1). N. mirabilis was the most dominant species, accounting for $90 \%$ of the total mysid population, and occurred almost exclusively at the nearshore station (Stn $A_{i}$ eelgrass bed), regardless of the time of day. Second in dominance was N. awatschensis (Brandt, 1851), which accounted for $8 \%$ of the total catch; its occurrence was also limited to the

Table 1. Diel and vertical variation in mean $( \pm \mathrm{SD})$ density of mysids (ind. $\mathrm{m}^{-3}$ ) collected at 2 sampling sites during the day and at night in Saroma-ko lagoon. The superscript lowercase letters indicate a significant difference between sampling layers ( $p<0.01,1$-way ANOVA and Tukey's post-hoc test). S: surface (under sea-ice), M: middle layer, B: near bottom, n: number of sampling times, (-) no occurrence

\begin{tabular}{|c|c|c|c|c|c|}
\hline \multirow[t]{2}{*}{ Species } & \multirow{2}{*}{$\begin{array}{l}\text { Sampling } \\
\text { layer }\end{array}$} & \multicolumn{2}{|c|}{ Stn A (near-shore) } & \multicolumn{2}{|c|}{ Stn B (off-shore) } \\
\hline & & $\begin{array}{l}\text { Day } \\
(\mathrm{n}=5)\end{array}$ & $\begin{array}{l}\text { Night } \\
(\mathrm{n}=4)\end{array}$ & $\begin{array}{c}\text { Day } \\
(\mathrm{n}=4)\end{array}$ & $\begin{array}{l}\text { Night } \\
(\mathrm{n}=1)\end{array}$ \\
\hline \multirow{3}{*}{$\begin{array}{r}\text { Neomysis } \\
\text { mirabilis }\end{array}$} & S & $4.5 \pm 4.8^{\mathrm{a}}$ & $9.4 \pm 5.9$ & - & - \\
\hline & $\mathrm{M}$ & $4.1 \pm 2.4^{\mathrm{a}}$ & $21.6 \pm 10.8^{b}$ & - & 0.7 \\
\hline & $\mathrm{B}$ & $2.7 \pm 2.5^{\mathrm{a}}$ & $8.8 \pm 8.9$ & - & - \\
\hline \multirow{3}{*}{$\begin{array}{l}\text { Neomysis } \\
\text { awatshensis }\end{array}$} & S & $1.4 \pm 2.4$ & $1.2 \pm 1.4$ & - & - \\
\hline & M & $0.4 \pm 0.6$ & $0.2 \pm 0.4$ & - & - \\
\hline & $\mathrm{B}$ & $0.3 \pm 0.7$ & $0.4 \pm 0.8$ & - & - \\
\hline \multirow{3}{*}{$\begin{array}{l}\text { Neomysis } \\
\text { czerniawskii }\end{array}$} & S & - & - & - & 1.4 \\
\hline & $\mathrm{M}$ & - & - & - & 0 \\
\hline & B & - & - & - & 1.7 \\
\hline \multirow{3}{*}{$\begin{array}{l}\text { Boreoacanthomysis } \\
\text { sherenki }\end{array}$} & S & - & - & - & 0.7 \\
\hline & $M$ & $0.1 \pm 0.3$ & - & - & - \\
\hline & $\mathrm{B}$ & $0.7 \pm 1.5$ & - & - & - \\
\hline
\end{tabular}


near-shore station day and night. In contrast, a small number of $N$. czerniavskii (Derzhavin, 1913) were only captured at night at the offshore station (Stn B, muddy bottom). Another uncommon species, Boreoacanthomysis schrencki (Czerniavsky, 1882), was collected from Stn A during the day and was only found at Stn B at night.

Further analyses of distribution patterns and gut pigment contents were conducted for the most abundant species, N. mirabilis, at Stn A. During the day, $N$. mirabilis was distributed throughout the water column, although its mean density tended to increase with increasing distance from the bottom (Table 1). At night, the density of $N$. mirabilis was 2 to 5 times
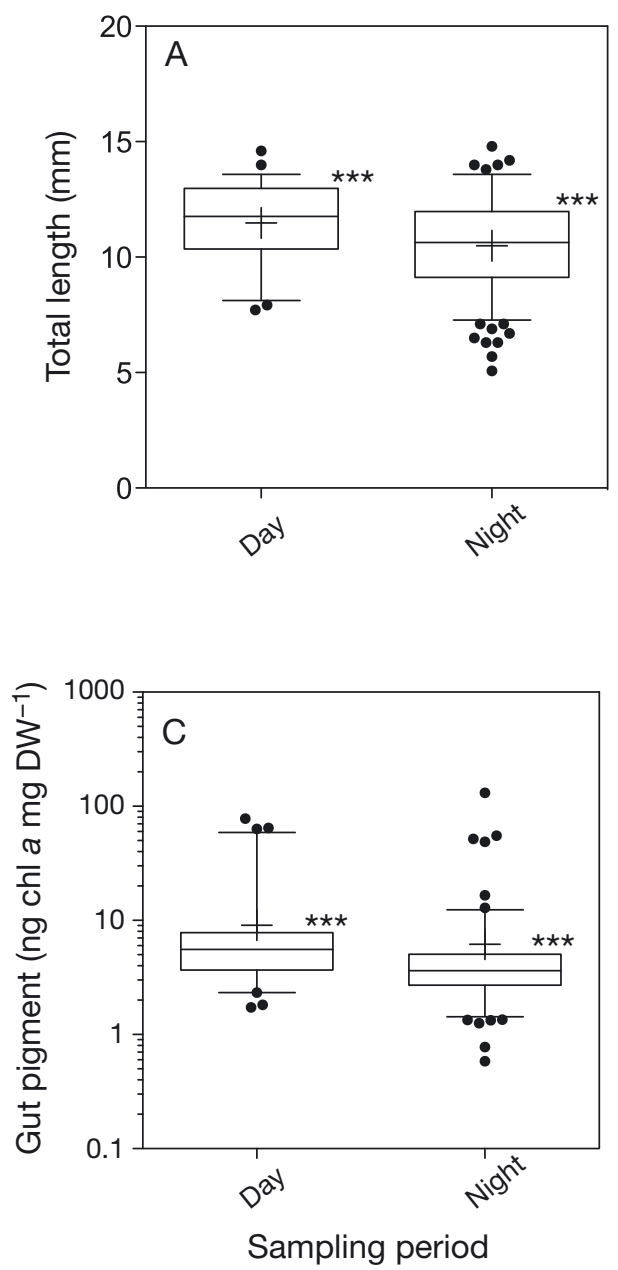

that of the day throughout the water column (Table 1). All individuals collected were immature males, and the mean TL of the mysids collected at night $(10.5 \mathrm{~mm})$ was significantly smaller than that of the mysids collected during the day $(11.5 \mathrm{~mm}$, Student's $t$-test, $\mathrm{p}<$ 0.05; Fig. 2A). This difference was attributed to an increase of smaller individuals in the middle and near-bottom layers at night (Fig. 2B).

The gut pigment contents of $N$. mirabilis varied widely, from 0.6 to $130.8 \mathrm{ng} \mathrm{chl}$ a $\mathrm{mg} \mathrm{DW}^{-1}$, and the mean value at night was significantly lower than that during the day (6.2 vs. $9.5 \mathrm{ng} \mathrm{chl}$ a $\mathrm{mg} \mathrm{DW}^{-1}$, respectively; Student's $t$-test, $\mathrm{p}<0.05$; Fig. $2 \mathrm{C}$ ). A significant difference in gut pigment contents was found in
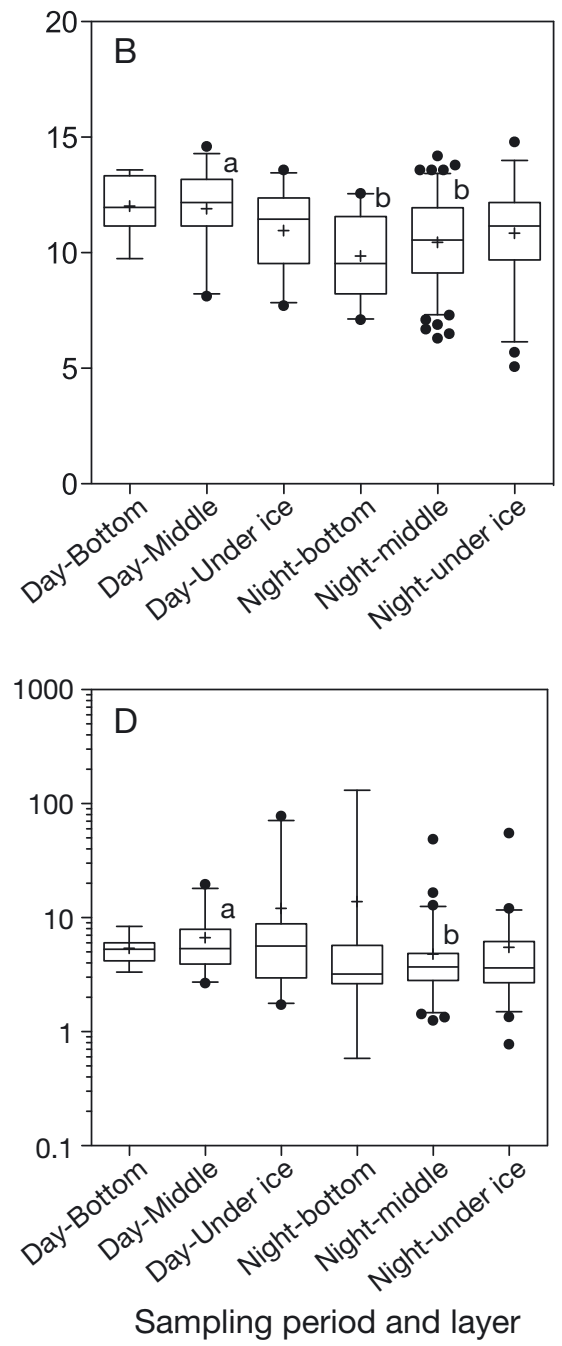

Fig. 2. Diel and spatial variations in body length and gut pigment content in a Neomysis mirabilis population at a near-shore eelgrass bed (Stn A) in Saroma-ko lagoon under seasonal sea ice. (A) Diel changes in mean body length; (B) spatio-temporal variation in mean body length; $(\mathrm{C})$ diel changes in mean gut pigment content; (D) spatio-temporal variations in mean gut pigment content. Crosses in the box and whisker plots indicate the mean, the central line in the box is the median, and the box limits are the 25 and $75 \%$ quartiles. The whiskers cover 5 to $95 \%$ of the data, and dots indicate outliers. ${ }^{* * *}$ indicates a significant difference between 2 bars ( $p<0.05$; Student's $t$-test). Different lowercase letters indicate a significant difference between 2 bars $(\mathrm{p}<0.05$; 1 -way ANOVA with Tukey's post-hoc test) 
the middle layer population between day and night (1-way ANOVA with Tukey's post-hoc test, p $<0.05$; Fig. 2D).

All $N$. mirabilis stomachs examined by SEM were full of prey items, regardless of sampling time (Fig. 3A). Benthic pennate diatoms Cocconeis spp. were the most common throughout the diel cycle (Fig. 3B). Other pennate diatoms, such as Synedra spp. (Fig. 3C) and Navicula spp. (Fig. 3D) were found in 30 and $10 \%$ of individuals collected during the day and night, respectively. Fragments of crustaceans, including benthic harpacticoid copepods (Fig. 3E,F), were also found in some individuals, but their frequency was relatively low $(<10 \%)$. A few dinoflagellates or ciliates were found in $10 \%$ of individuals collected during the day.
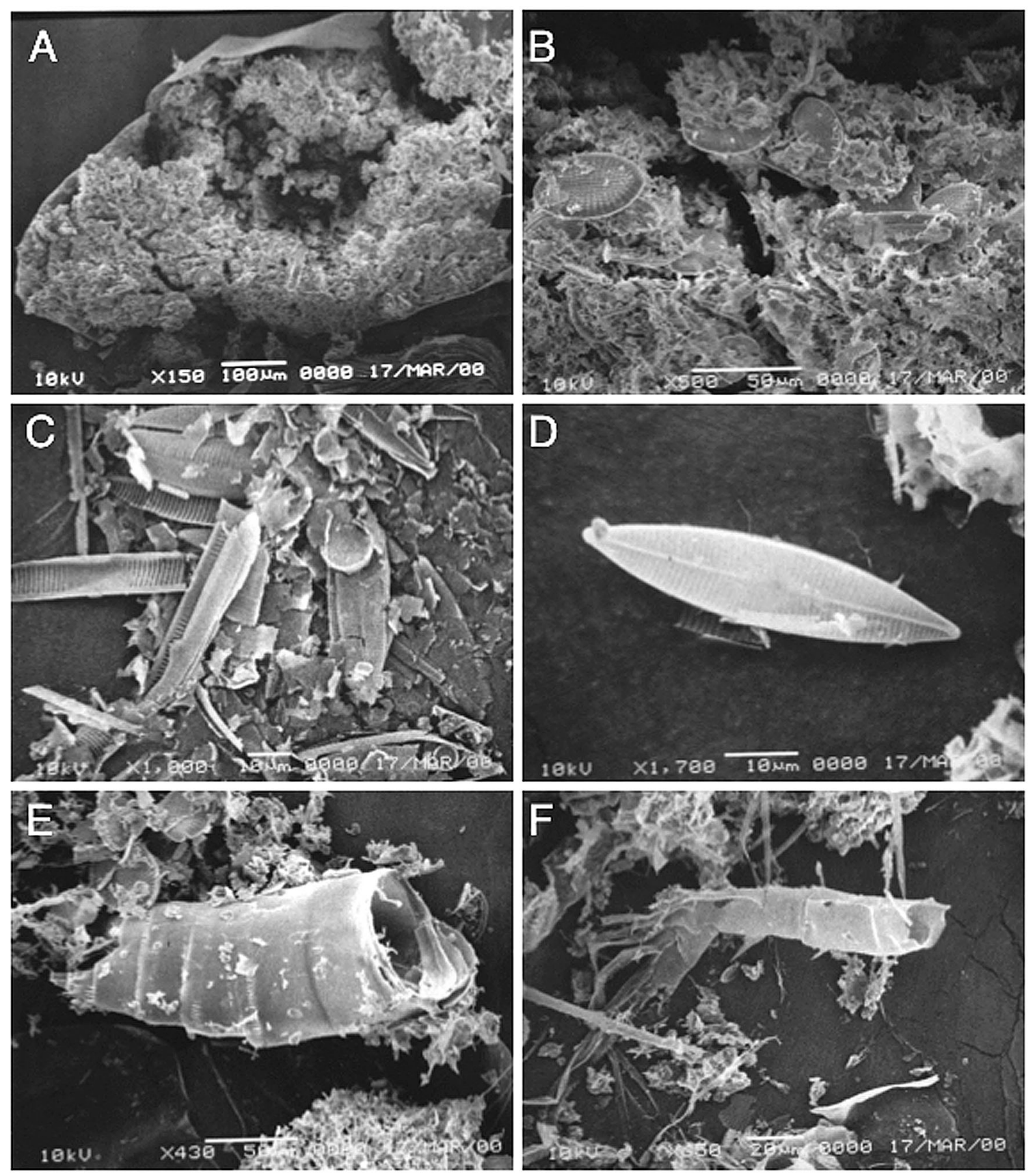

Fig. 3. Scanning electron microscope photographs of the foregut contents of Neomysis mirabilis collected in near-shore eelgrass beds under seasonal sea ice. (A) Whole view of stomach contents; (B) unidentified material, and the diatom Cocconeis spp.; (C) Synedra spp.; (D) Navicula sp.; (E) abdomen of harpacticoid copepods; (F) unidentified crustacean parts 
Microscopic observations of microalgae in their various habitats under the sea ice showed that assemblages of epiphytes on the eelgrass were distinctly different from those of phytoplankton and ice algae assemblages (Fig. 4). Epiphytes on eelgrass were dominated by Cocconeis spp., which accounted for $85 \%$ of the total cells studied, with small numbers of Odontera spp., Synedra spp., Navicula spp. and Pleurosigma spp. In contrast, the diatoms Fragilariopsis spp. and Detonula spp. were dominant in phytoplankton and ice algae assemblages, accounting for more than $60 \%$ of the total cells investigated, whereas the occurrence of Cocconeis spp. in the phytoplankton and ice algae assemblages was extremely limited ( $<3 \%$ of the total cells studied).

Daily carbon ingestion by $N$. mirabilis in the form of algal prey was variable, depending on size, and in general their importance as an energy source increased with mysid size (Table 2). For example, for medium-sized (10.6 mm TL) and large specimens $(13.1 \mathrm{~mm})$, the daily ingestion of algal prey fulfilled their metabolic requirements for respiration, whereas in small specimens $(7.8 \mathrm{~mm})$, the daily ingestion of algae only satisfied $70 \%$ of their metabolic requirements.

\section{DISCUSSION}

Among the 4 species of mysids collected in this study, Neomysis mirabilis was the most dominant, accounting for $90 \%$ of the total mysid population under the sea ice. As found in this study, this species occurs abundantly in eelgrass beds along the coastal zone of the subarctic north-western Pacific (Pecheneva et al. 2002, Yamada et al. 2007, Yusa \& Goshima 2011). Zelickman (1974) observed the behaviour of this species in the field, and reported that it formed ribbons or spherical swarms in the eelgrass bed, and

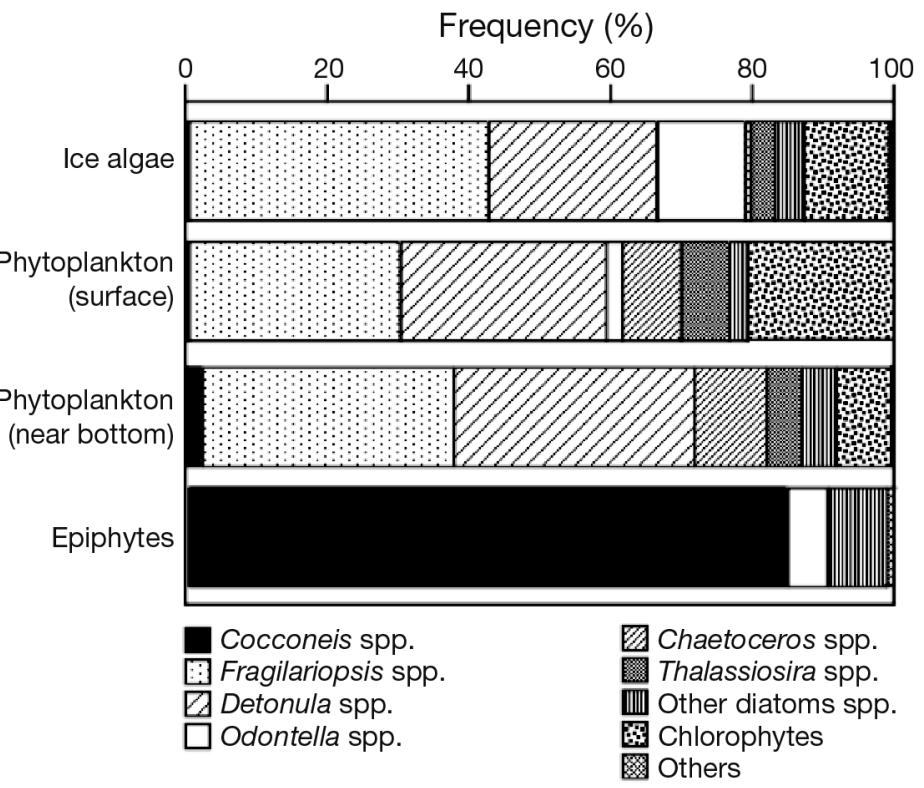

Fig. 4. Composition of algal cells from various Neomysis mirabilis habitats under seasonal sea ice at Stn A (near-shore eelgrass bed)

remained at the same location for several hours. The present study also found that $N$. mirabilis is located in eelgrass beds throughout the diel cycle under sea ice; however, some individuals exhibited diel migration within, or outside of, the eelgrass beds. For example, the density of $N$. mirabilis in eelgrass beds in the middle layer at night was significantly higher than that during the day (Table 1). Net avoidance by mysids may partly explain this difference; however, a large proportion of the population seemed to nocturnally migrate to the eelgrass beds, since the increase in density was mainly due to an increase in small individuals (Fig. 2A,B) which have a relatively low escape ability (Fleminger \& Clutter 1965). Zelickman (1974) reported that $N$. mirabilis swarmed in the shadow of the water's edge during the day, but disappeared at night. He also observed that in the light, young $N$. mirabilis in an aquarium always stayed

Table 2. Estimated daily ingestion of algal prey based on gut pigment content in Neomysis mirabilis in an eelgrass bed under sea ice. Minimum carbon requirements to maintain metabolism are also noted. Daily algal ingestion was estimated with pigment destruction $=90 \%$. Assimilated carbon was estimated with a C:chl a ratio of 47.63 and an assimilation efficiency of $80 \%$. Metabolic requirements were estimated based on the relationship between body dry weight and oxygen consumption rate (Ikeda 1985)

\begin{tabular}{|c|c|c|c|c|c|}
\hline $\begin{array}{l}\text { Size } \\
\text { class }\end{array}$ & $\begin{array}{l}\text { Total length } \\
\text { (mm) } \\
\text { Mean (range) }\end{array}$ & $\begin{array}{c}\text { Daily algal } \\
\text { ingestion } \\
\text { (ng chl } a \text { ind. } .^{-1} \mathrm{~d}^{-1} \text { ) }\end{array}$ & $\begin{array}{c}\text { Assimilated } \\
\text { carbon } \\
\left(\mu \mathrm{g} \mathrm{C} \text { ind. } .^{-1} \mathrm{~d}^{-1}\right)\end{array}$ & $\begin{array}{c}\text { Metabolic } \\
\text { requirement } \\
\left(\mu g \mathrm{C} \text { ind } .^{-1} \mathrm{~d}^{-1}\right)\end{array}$ & $\begin{array}{l}\text { \% Assimilated } \\
\text { carbon to metabolic } \\
\text { requirement }\end{array}$ \\
\hline Small & $7.8(5.1-8.9)$ & 128.5 & 4.9 & 6.8 & 73 \\
\hline Medium & $10.6(9.1-12.0)$ & 360.1 & 13.7 & 13.0 & 106 \\
\hline Large & $13.1(12.2-14.8)$ & 1263.6 & 48.1 & 20.5 & 235 \\
\hline
\end{tabular}


away from larger individuals. Therefore, we suggest that small $N$. mirabilis migrate into the eelgrass beds at night from shallower habitats, whereas larger individuals remain in the eelgrass beds throughout the diel cycle.

The gut pigment contents of $N$. mirabilis were relatively constant throughout the day, but were significantly lower at night (Fig. 2C). We attributed this decrease to the occurrence of small mysids in the middle and near-bottom layers at night (Table 1, Fig. 3B,D). However, SEM observations revealed that benthic diatoms Cocconeis spp. and unidentified amorphous material were the most common prey, regardless of the time of day (Fig. 3). Microscopic analysis revealed that Cocconeis spp. only dominated in the eelgrass epiphyte assemblages (Fig. 4), as reported in previous studies (Sieburth \& Thomas 1973, Nakaoka et al. 2001). Therefore, we conclude that $N$. mirabilis is primarily an epiphyte grazer under the sea ice during the winter. Daily ingestion, estimated by the gut pigment method, indicated that epiphytes were an adequate food source for metabolism maintenance in medium-sized and large mysids, which were located in the eelgrass beds throughout the day (Table 2). However, our calculations indicated that epiphytes alone were not sufficient to support the metabolic rates of small mysids. Cocconeis spp. have a highly adhesive, prostrate form (Moore 1975), and cannot easily be eaten by smaller mysids (ca. $<10 \mathrm{~mm} \mathrm{TL}$ ) that do not have fully developed grazing capabilities (Table 2). Therefore, planktonic and benthic copepods are important to small mysids in fulfilling their metabolic requirements. The nocturnal increase of small mysids in the middle and near-bottom layers may be due to foraging for such prey organisms in those areas. Although ontogenetical changes in diet by mysids has been largely studied from the view point of the development of predatory ability on animal prey (Siegfried and Kopache 1980, Branstrator et al. 2000, Viherluoto et al. 2000), this study suggests that the importance of animal prey is higher in younger mysids when grazing is a primary foraging mechanism.

This study found that during the winter, N. mirabilis depends mainly on eelgrass epiphytes as a food source under the sea ice, in addition to small crustaceans. In general, many mysid species, including Neomysis, are known to alternatively adopt 2 different feeding modes: suspension feeding and predation (Mauchline 1980, Takahashi 2004). The results of this study suggest that grazing on epiphytes may be a third alternative in the feeding habits of mysids that inhabit eelgrass beds. The importance of epi- phytes as a food source has also been reported in $N$. integer in brackish lakes in the United Kingdom (Irvine et al. 1993). Hasegawa et al. (2007) reported that the density of epiphytes in Akkeshi-ko estuary, south-eastern Hokkaido, reaches its annual maximum in November, just before the sea ice forms. This suggests that epiphytes are the most easily obtainable food items during the winter, when primary and secondary productivity in the water column decreases. Given their wide range of gut fluorescence values, however, dependency on the epiphytes could also vary intra-specifically, particularly in smaller mysids. The flexible feeding habits of $N$. mirabilis (switching feeding modes depending on food availability) are beneficial to maintaining their high biomass, even during the winter, and consequently result in mysids being important prey for commercially important fish and crustaceans, particularly during the winter and spring.

Acknowledgements. We thank H. Hattori, H. Saito and others from the Saroma Aquaculture and Research Institute for their help in the field. We are also grateful to Y. Niimura for assisting with the algal identifications. SEM observations were supported by T. Suzuki and T. Toda. The study was partly supported by a Sasakawa Scientific Research Grant from The Japan Society and a Grant-in-Aid for Scientific Research (B) from the Ministry of Education, Science, Sports and Culture to K.T. (24310007).

\section{LITERATURE CITED}

Aya FA, Kudo I (2007) Isotopic determination of Japanese scallop Patinopecten (Mizuhopecten) yessonsis (Jay) tissues shows habitat-related differences in food sources. J Shellfish Res 26:295-302

Baldo-Kost ALB, Knight AW (1975) The food of Neomysis mercedis Holmes in the Sacramento-San Joaquin estuary. Calif Fish Game 61:35-46

> Branstrator KD, Cabana G, Mazumder A, Rasmussen JB (2000) Measuring life-history omnivory in the opossum shrimp, Mysis relicta, with stable nitrogen isotopes. Limnol Oceanogr 45:463-467

Chipps SR (1998) Temperature-dependent consumption and gut-residence time in the opossum shrimp Mysis relicta. J Plankton Res 20:2401-2411

$>$ De Jonge VN (1980) Fluctuations in the organic carbon to chlorophyll a ratios for estuarine benthic diatom populations. Mar Ecol Prog Ser 2:345-353

Fleminger A, Clutter RI (1965) Avoidance of towed nets by zooplankton. Limnol Oceanogr 10:94-104

Fockedey N, Mees J (1999) Feeding of the hyperbenthic mysid Neomysis integer in the maximum turbidity zone of the Elbe, Westerschelde and Gironde estuaries. J Mar Syst 22:207-228

Fortier M, Fortier L (1997) Transport of marine fish larvae to Saroma-ko Lagoon (Hokkaido, Japan) in relation to the availability of zooplankton prey under the winter ice cover. J Mar Syst 11:221-234 
Fortier L, Fortier M, Demers S (1995) Zooplankton and larval fish community development: comparative study under first-year sea ice at low and high latitudes in the northern hemisphere. Proc NIPR Symp Polar Biol 8:11-19

Fukuchi M, Tanimura A, Hoshiai T (1979) 'NIPR-I', a new plankton sampler under sea ice. Bull Plankton Soc Japan 26:104-109

Gnaiger E (1983) Calculation of energetic and biochemical equivalents of respiratory oxygen consumption. In: Gnaiger E, Forstner H (eds) Polarographic oxygen sensors. Springer, New York, NY, p 337-345

Hasegawa N, Hori M, Mukai H (2007) Seasonal shifts in seagrass bed primary producers in a cold-temperate estuary: dynamics of eelgrass Zostera marina and associated epiphytic algae. Aquat Bot 86:337-345

Ikeda T (1985) Metabolic rates of epipelagic marine zooplankton as a function of body mass and temperature. Mar Biol 85:1-11

Irvine K, Moss B, Bales M, Snook D (1993) The changing ecosystem of a shallow, brackish lake, Hickling Broad, Norfolk, UK. I. Trophic relationships with special reference to the role of Neomysis integer. Freshw Biol 29: 119-139

Katsuki K, Seto K, Nomura R, Maekawa K, Khim BK (2009) Effect of human activity on Lake Saroma (Japan) during the past 150 years: evidence by variation of diatom assemblages. Estuar Coast Shelf Sci 81:215-224

> Mackas DL, Bohrer R (1976) Fluorescence analysis of zooplankton gut contents and investigation of diel feeding patterns. J Exp Mar Biol Ecol 25:77-85

Mauchline J (1980) The biology of mysids and euphausiids. Adv Mar Biol 18:1-681

McMinn A, Hirawake T, Hamaoka T, Hattori H, Fukuchi M (2005) Contribution of benthic microalgae to ice covered coastal ecosystems in northern Hokkaido, Japan. J Mar Biol Assoc UK 85:283-289

Moore JW (1975) The role of algae diet of Asellus aquaticus L. and Gammarus pulex L. J Anim Ecol 44:719-730

Nakaoka M, Toyohara T, Matsumasa M (2001) Seasonal and between-substrate variation in mobile epifaunal community in a multispecific seagrass bed of Otsuchi Bay, Japan. Mar Ecol 22:379-395

> Pecheneva NV, Labai VS, Kafanov AI (2002) Bottom communities of Nyivo Lagoon (northeastern Sakhalin). Russ J Mar Biol 28:225-234

Pezzack DS, Corey S (1982) Effects of temperature and salinity on immature and juvenile Neomysis americana (Smith) (Crustacea; Mysidacea). Can J Zool 60:2725-2728

Roast SD, Widdows J, Jones MB (1999) Respiratory re-

Editorial responsibility: Bernard Sainte-Marie,

Mont-Joli, Quebec, Canada sponses of the estuarine mysid Neomysis integer (Peracarida: Mysidacea) in relation to a variable environment. Mar Biol 133:643-649

Shushkina EA, Kuz'micheva VU, Ostapenko LA (1971) Energy equivalent of body mass, respiration and calorific value of mysids from the Sea of Japan. Oceanology 12: 880-889

Sieburth J, Thomas CD (1973) Fouling on eelgrass (Zostera marina L.). J Phycol 9:46-50

> Siegfried CA, Kopache ME (1980) Feeding of Neomysis mercedis (Holmes). Biol Bull (Woods Hole) 159:193-205

Simmons MA, Knight AW (1975) Respiratory response of Neomysis intermedia (Crustacea: Mysidacea) to changes in salinity, temperature and season. Comp Biochem Physiol A 50:181-193

Suzuki R, Ishimaru T (1990) An improved method for the determination of phytoplankton chlorophyll using N,Ndimethylformamide. J Oceanogr Soc Jpn 46:190-194

Tada K, Kurata M, Nishimura Y (1993) Seasonal changes of chlorophyll $a$ and nutrients in Lake Saroma. Bull Plankton Soc Japan 39:163-165

Taguchi S, Takahashi M (1993) Summary of the colloquium. In: Taguchi S, Takahashi M (eds) Plankton colloquium: ecosystem of Lake Saroma under sea ice covered condition in winter. Bull Plankton Soc Japan 39:152-154

Takahashi K (2004) Feeding ecology of mysids in freshwater and marine coastal habitats: a review. Bull Plankton Soc Japan 51:46-72 (in Japanese with English abstract)

Toda T, Suh HL, Nemoto T (1989) Dry fracturing: a simple technique for scanning electron microscopy of small crustaceans and its application to internal observations of copepods. J Crustac Biol 9:409-413

> Viherluoto M, Kuosa H, Flinkman J, Viitasalo M (2000) Food utilization of pelagic mysids, Mysis mixta and M. relicta, during their growing season in the northern Baltic. Mar Biol 136:553-559

Yamada K, Takahashi K, Vallet C, Taguchi S, Toda T (2007) Distribution, life history, and production of three species of Neomysis in Akkeshi-ko estuary, northern Japan. Mar Biol 150:905-917

> Yamada K, Hori M, Tanaka Y, Hasegawa N, Nakaoka M (2010) Contribution of different groups to the diet of major predatory fishes at a seagrass meadow in northeastern Japan. Estuar Coast Shelf Sci 86:71-82

Yusa T, Goshima S (2011) Life history of Neomysis mirabilis (Crustacea: Mysidacea) in Notoro Lagoon, Hokkaido, Japan. Crustac Res 40:81-92

- Zelickman EA (1974) Group orientation in Neomysis mirabilis (Mysidacea: Crustacea). Mar Biol 24:251-258

Submitted: August 13, 2014; Accepted: January 5, 2015 Proofs received from author(s): February 9, 2015 